\title{
The Involvement of Religious Communities in the teaching of Multi-faith Syllabus in Botswana Junior Secondary Schools
}

\author{
C. Masheko, A. Bhicoo, T. Dema, M. Mosweu, T. Thekiso and S. Mmolai
}

\begin{abstract}
Prior to 1996, Religious Education (RE) in Botswana junior secondary schools was Christian based and there were no significant disparities in academic performance between RE and other subjects. Since the introduction of a multi-faith syllabus there has been a decline in the academic performance in this subject. Perhaps this situation emanates from the fact that most RE teachers and students are Christians. Possibly, Christian teachers and students may not be familiar with the dimensions of other world religions explored in this syllabus. This study was therefore carried out to investigate if the involvement of religious communities could be of assistance in the teaching and learning of the multi-faith syllabus in Botswana junior secondary schools. The study used random, purposive and convenience sampling techniques to select the population from twelve (12) junior secondary schools and seven (7) religions. Data was collected from thirty-six (36) RE teachers, one hundred and twenty (120) students and fifty-six (56) representatives of the seven (7) religions prevalent in Botswana and explored in this syllabus. The study used questionnaires and interviews to collect data. The findings of this study revealed that the involvement of religious communities in the teaching and learning of multi-faith syllabus in Botswana junior secondary schools is capable of assisting in knowledge acquisition of the various religions explored in this syllabus by providing first-hand information from adherents of the explored religions. This study therefore recommends that the Ministry of Basic Education, School Management Teams and Parents and Teachers Associations should encourage the involvement of religious communities as an attempt to improve RE Junior Certificate results.
\end{abstract}

Key Words: Religious Education, multi-faith, junior secondary schools, phenomenological approach, interpretive approach, religious communities, involvement, Botswana

\section{INTRODUCTION}

Religious Education (RE) is a subject in the school curriculum that is concerned with the teaching about different religions. Traditionally, the teaching about religion in Botswana was mainly meant to impart the norms, customs and the values of the society (Tlokwe, 2001; Ramahobo, 1990). The inclusion of religion was therefore an integral part of traditional education, even though it was not in a school set-up. During this time, religious communities' involvement in the teaching of religion was prevalent, since elders and all parents from different traditional communities transmitted social, religious and moral beliefs and values to the children (Amanze, 2002; Dinku 2002; Mmolai, 1988).

The introduction of western education among Batswana (the people of Botswana) began around the 19th and the 20th centuries and RE at the time was called Scripture (Mmolai, 1999; Kgokgwe, 1996). At this embryonic stage of the subject, there was no prescribed syllabus; the different Christian missionary societies taught different Christian syllabi relevant to their own societies (Nkomazana, 2007). Following the 1931 Policy which placed the running of the schools under the village committees, a uniform Bible Knowledge (BK) syllabus was introduced across mission schools in different societies among Batswana (Matemba, 2005). It 
is important to note that at this level community involvement was significant as the teaching was done by the converted members of the community.

After Botswana got independence in 1966, mission schools continued to offer the BK syllabus. However, following the recommendations of the first Botswana National Policy on Education (Botswana Government, 1977), BK was replaced with Religious and Moral Education (R and ME) in Botswana junior secondary schools (Mmolai, 1999). During the late 1980's and early 1990's RE scholars advocated for the change of R and ME syllabus from Christian confessional approach to any model that would appreciate the religious diversity in the country (Morake, 1993, Seretse, 1990).

Following the recommendations of the 1994 Revised National Policy on Education, Moral Education (RE) and Religious Education (ME) were separated within the Botswana junior secondary curriculum. Consequently, in 1996 the multi-faith RE syllabus was introduced as an optional subject in the junior secondary schools. Despite the fact that religions included in the syllabus were accessible around the country, the syllabus was more of descriptive and did not give the students an opportunity to interact with the adherents of the religions explored in the syllabus (Matemba, 2005).

This syllabus was reviewed in 2007 and the second multi-faith syllabus was introduced in 2010. Advocates of the multi-faith teaching encourage involvement of religious communities in the teaching and learning process. For instance, Becker (2001) argues that for students to understand these religions, it is very important that religious communities are involved so that students can view these religions as existing and real. Whilst the approach of the second syllabus is interpretive, the religious communities were not involved in both the review and implementation workshops. At present, these communities are also not actively involved in the teaching and learning process of this syllabus.

\section{Statement of the Problem}

The 1994 Revised National Policy on Education recommends the improvement of partnership between schools and the community in the development of education (Botswana Government, 1994). Since the multi-faith syllabus involves different religions, the involvement of religious communities is essential. Perhaps lack of involvement of religious communities in the teaching of RE in Botswana negatively affects the teaching and learning process, hence the low pass rate in this subject. For instance, percentages of JCE results reveal that since 2012 candidates awarded Grade $\mathrm{C}$ or better in this subject have been lower than $40 \%$ (Botswana Examinations Council, 2013).

\section{Purpose of the Study}

The purpose of the study was to investigate and explore the involvement of the religious communities in the teaching of the multi-faith syllabus in Botswana. The study intended to find out the extent to which these religious communities are involved and the benefits of their involvement.

The study furthermore investigated possible impediments to the involvement of religious communities in the teaching of the multi-faith syllabus in junior secondary schools in Botswana.

\section{RESEARCH QUESTIONS}

The study sought to answer the following questions: 
1. To what extent is the involvement of religious communities in the teaching of a multifaith syllabus in Botswana junior secondary schools?

2. What are the main benefits associated with involving religious communities in the teaching and learning of a multi-faith syllabus in Botswana junior secondary schools?

3. What are the possible impediments of involving religious communities for the teaching and learning of Religious Education?

\section{REVIEWED LITERATURE \\ Historical Background of Multi-faith Teaching Introduction}

Even though in 1996 the teaching of multi-faith was new in Botswana, there were some countries in the world where the syllabus was in use such as the United Kingdom. The seed was first sworn in the late 1960s by Ninian Smart in Lancaster, UK by introducing the "phenomenological" or non-dogmatic approach to the teaching of RE (Schools Council, 1971). In response to the critics of this approach, Robert Jackson from the University of Warwick introduced the interpretive approach (Jackson, 1997).

\section{The Phenomenological Approach}

This approach defines religion as a mode of interpreting and understanding experiences. In this approach teachers have to present content in a way that will enable students to have a feeling of being a religious believer from the inside (Schools Council, 1971). This approach was supported by other scholars who viewed it as having the capability of broadening the scope of RE by removing it from a spiritual and historical approach to a more open and liberal way of treating religion (Hull, 1982; Grimmit, 1987; Thompson, 2004). Most schools especially in England and Wales adopted the phenomenological approach of teaching multi-faith RE.

\section{The Interpretive Approach}

The interpretive approach was from a project which was a joint venture of Robert Jackson and some students at the University of Warwick in the UK. The project aimed at discovering the approach that will form a link between the content that children learn and the practical life they live (Jackson, 1997). According to Jackson, this approach is an attempt to move away from the descriptive method to a reflective model that will enhance transformative education by allowing students to make comparison and contrast between their own concepts and those of the "insider".

The interpretive approach encourages students' sensitivity in order to develop a sense of empathy after engaging with other people's religions. Since the aim of this method is to bring the dimensions of religious diversity into cultural education (Jackson, 2004), community involvement in the learning process is inevitable because learners' practical life involves the parents at home and other religious communities they interact with.

\section{Involving Religious Communities in the teaching and learning of Multi faith Syllabus}

Education systems across the world encourage shared responsibilities between several stakeholders such as the teachers, students, parents and the entire community (Epstein, 2001; Ornstein, Levine, Gutek \& Vocke, 2013). Consequently, community involvement in children's education is in the top agenda of discussions in the world (Kumar, 2010; Uemura 1999; Desforges \& Abouchaar, 2003). 
The transition from the phenomenological approach to interpretive one was meant to bring a close relationship between the students' own religions and those of others. In this approach, the ethnographic research methodology is encouraged where teachers and learners could learn different religions within the natural environments of their adherents; this would lead to the active involvement of the different religious communities in the teaching and learning of their religions (Nesbitt, 2004).

The interpretive approach encourages stimulation of insights and experiences of the students which they draw from the community, where students have to make meaning of the world around them through interaction (Jackson, 1997). There are various advantages of involving different religious communities in any teaching and learning process of multi-faith RE. For instance, the religious communities could assist teachers with first-hand information from their religions. As argued Singh, Bickley, Keith, Trivette and Anderson (1999), while the function of the home and the religious community is to nurture and direct a child in a particular faith; the school facilitates learning by showing learners the diversity of belief systems and the significance of individuals in the community.

Religious communities can also contribute in the creating, adapting and proposing curricula for RE (Miroshnikova \& Davis, 2013). For instance, as observes Uemura (1999), if children have learnt from the community then they will be equipped with the relevant skills and information that is needed by the society. Desforges and Abouchaar (2003) also support community involvement because it is capable of boosting learners' motivation and level of participation. This, as they argue, could in turn improve the RE results.

However, it has to pointed out that although community involvement has some significant advantages to the teaching of multi-faith RE, promoting and implementing community involvement in the teaching of this subject has both social and political challenges which are capable of impeding the effective teaching and learning process (Cheng, 2005). For example, as observes Chidester (1996), in South Africa when some people were suggesting the shift from teaching a Christian based RE to a multi-faith syllabus, others in the community were against the change. The opponents of such a shift argued that only Christianity has to be taught because it has a lot of following in South Africa as compared to other religions. Arguably, this attitude, which is capable of promoting intolerance, illustrates a challenge emanating from the involvement of the community in the teaching of this subject.

Seemingly, in Botswana the introduction of other world religions in the secondary RE syllabus was received with mixed feelings mainly because Christianity was already established in the country; with significant influence on some social and political institutions. Hence, the community perceived the teaching of different religions as degrading the status of Christianity in the country (Mmegi, 16th November 2004:4). Furthermore, media even attested that if both Islam and Christianity were taught, there would be disorder and turmoil in the country (Botswana Guardian, 31st March 2000:2). Such views confirm that community involvement is capable of instigating social and political challenges as those involved could wish to serve their interests. Interestingly, since the community always feels responsible for the moral and religious aspects of their society, RE and ME seem to be more affected by the challenges of community's involvement, in comparison to other subjects. This being the case, whilst it is significant to involve religious communities in the teaching and learning of the RE multi-faith syllabus in Botswana, teachers have to be very cautious when implementing such an approach. 


\section{METHODOLOGY}

As an attempt to provide comprehensive findings regarding the involvement of religious communities in the teaching of a multi faith RE syllabus in Botswana junior secondary schools, this study used both quantitative (questionnaires) and qualitative (interviews) methods to collect data. Questionnaires and interviews were mainly preferred because they complement each other; while questionnaires provide basic facts, interviews provide more in-depth information on issues under investigation (Cottrell \& McKenzie, 2011; Muijs, 2011). This study was carried out in Gaborone (the capital city), which has all the religions practised in Botswana. A total of 212 participants consisting of 120 RE students ( 60 boys and 60 girls), 36 $\mathrm{RE}$ teachers and 56 religious community representatives participated in this study. RE teachers were sampled because they have concrete information as to whether different religions are being involved in the teaching of $\mathrm{RE}$ or not. Teachers were also relevant in providing information about their attempts of involving these religious communities in their teaching. Students were involved in the study in order to express their views regarding the involvement of religious communities in the teaching of this subject. Representatives from the seven different religions practiced in Botswana (explored in the syllabus) were included in the study in order to explain whether their religious communities collaborate with RE teachers as an attempt to achieve the intended goals of the syllabus in the promotion of tolerance between adherents of different religions.

Permission to conduct the study was sought from the Ministry of Basic Education, school heads and religious leaders. Permission for the leaners' participation in the study was specifically sought from the parents who signed the consent form and returned it to the school. Thereafter, students' written assent was required from participating students. All participants were assured about the confidentiality of information they provided. All participants were advised not to indicate their names during the entire study.

Participating students were picked at random to enable them an equal chance of being selected (Krysik \& Finn, 2013). This technique is also more representative, less variable and it allows for comparisons (Cargan, 2007). Another benefit of this system is that it is less costly because of its increased efficiency (Bhatti, 2007).

Convenience sampling technique was used to select teachers because it is rich in information, less demanding, quick and cheap (Irvine, 2011). Finally, purposive sampling was found to be most appropriate for selecting representatives of religious communities, since religious leaders (link persons) had to identify appropriate representatives from their respective religions.

The study employed qualitative and quantitative methods of data analysis. Quantitative data was coded and descriptive statistics were produced to establish frequencies and cross tabulations using the Statistical Package for Social Sciences (SPSS).

Recorders were used during interviews to improve reliability of the collected data and to facilitate data analysis. Content analysis was employed to evaluate qualitative data; after identifying themes which emerged from the interviews, data were coded into various categories. After coding, semantic relationships and patterns were established. 


\section{RESULTS AND DISCUSSION \\ Involvement of Religious Communities in the teaching of a Multi-Faith Syllabus}

Involving religious communities in the teaching of a multi-faith syllabus is an integral part of fulfilling the rationale of Botswana Junior Secondary RE in the curriculum, which is to help learners to be able to express their own religions, those of others and to encourage tolerance between people of different faiths (Botswana Government, 2008). Such an involvement is also capable of assisting RE teachers when exploring religions which they do not adhere to; they would acquire first-hand information from adherents. Seemingly, students could utilise religious communities in their surroundings as sources of information.

The relevant activities to the current multi-faith RE syllabus in Botswana junior secondary schools were the syllabus review and the implementation workshops. In search for the extent of the involvement of religious communities in the teaching and learning of this subject, it was therefore important to start by establishing the participation of these communities in these workshops. The findings pertaining to such an investigation reveal that the extent to which these different religious communities were involved in these two activities appears to be very minimal. For instance, an insignificant percentage of religious communities $(21.4 \%)$ confirm their involvement in the review of the RE syllabus. Interview data confirm this lack of participation, as majority of the respondents from the religious communities pointed out that they were not invited to the review workshop. The following verbatim quotes support this opinion:

We were not aware of the review of the syllabus because we were not invited. I only knew about it later when it was completed when I met the lady from the Curriculum Department and she casually informed me that it has been reviewed, apparently she knew me because I was involved in the formulation of the first syllabus back then around 1997.

We are not aware of the review but I remember we once prepared some material that contained the entire topics included in the syllabus about our religion and we presented the document to the Curriculum Department and some teachers, probably it was for the old syllabus I don't know.

Furthermore, teachers' interview responses on the same issue reveal majority not being aware of the involvement of religious communities in the syllabus review workshop. This being the case, it can be realised that religious communities did not take part in the review of the syllabus. These findings further reveal lack of religious participation in the implementation workshop. For instance, both teachers (66.7\%) and religious communities $(71.5 \%)$ indicate that these communities were not invited to the implementation workshop. Interview results support this, as illustrated by this comment by one of the teachers:

It was only the officers from the Curriculum Department, TT\&D and some teachers who presented some topics to us, there were no religious communities.

As can neb gathered from these findings, religious communities were not involved in both the review and implementation workshops. Perhaps, if religious communities were involved in the implementation workshops, they could have had an opportunity to share knowledge from their religions with participating teachers. This could have been a means of creating collaboration between religious communities and the teachers. Arguably, this collaboration is capable of enhancing acquisition of religious concepts from the explored world religions. 
On the basis of the findings of this study on this issue, it can be argued that if the involvement of religious communities in the teaching of multi-faith syllabus can be fully adopted and utilized in the Botswana junior secondary schools, it could possibly lead to improved results in $\mathrm{RE}$, which have been declining in the past years. As will emerge in the following discussion, involvement of these communities has essential benefits to both teachers and leaners of this subject.

\section{Main Benefits of the Involvement of Religious Communities}

Having established the extent of the involvement of religious communities to the teaching of a multi-faith syllabus in the Botswana junior secondary school RE syllabus, this study further sought the participants' perceptions pertaining to the main benefits of such an approach. To begin with, the findings of this study reveal that religious communities have relevant resources to the RE syllabus which they are prepared to share with the schools as teaching and learning aids. For example one representative of these communities stated that:

We do not have any problem to share some of our resources like pamphlets, Qur'an and videos on our teachings to students or teachers and our library is open to anyone who would like to learn about our religion.

Another representative of a different religious community further explained that they are always prepared and happy to welcome both learners and teaches to view their place of worship. Arguably, such educational visits are beneficial to both the learners and teachers since they will have an opportunity to touch, see and feel religious artefacts they have explored during the teaching and learning process.

The most significant finding of this study is that despite lack of participation in the above workshops, majority of teachers $(60.7 \%)$ and religious communities representatives (89.3\%) confirm that religious communities are prepared to collaborate with teachers in the teaching of a multi-faith RE. This willingness was confirmed by interview responses from representatives of these religions:

Yes we are willing, who wouldn't? Everyone else even from other religions would wish to be accorded such an opportunity.

Yes we are very much eager to be involved, In the past, I had picked some errors in the textbooks which means if given a chance, we could be able to rectify them to both teachers and the students therefore we are so much willing to be involved in schools.

To confirm the religious communities' argument, some teachers also indicated that the religious communities are willing to be involved. They pointed out that whenever they visit the places of worship the religious communities would be positive and welcoming, giving them all the information they need. For example, one teacher mentioned that:

I once visited the Sikh temple and was given a warm welcome and one of the members there told me that they really want to help schools in whatever way concerning their religion.

The religious communities' willingness to participate in the teaching of the multi faith syllabus is further confirmed by the following quote from one of the students: 
Maybe they would be willing to help because there was a time when I greeted one woman in the Islamic way 'Salam Ali Kum' she responded and told me that she was a Sikh and not a Muslim woman then further on explained to me about her religion.

In Botswana, all the religions that are included in the syllabus are easily accessible in many areas of the country, where teachers and learners could be able to contact them for assistance. For example, in the cities, towns and main villages the religions are well established; they have built some places of worship and some adherents own businesses in the country. In this way, learners easily interact with adherents of these religions, as confirmed by the above extract from the students' interviews. Once learners perceive these religious communities as sources of information, they would utilise their resources and relevant information in their search for knowledge in this subject.

If the relationship between the schools and the religious communities was intensified, learners would be able to relate what they learn at school with what they see and experience in the community as they relate with people of diverse religious backgrounds. Furthermore, whenever the content is of specific reference to these religions, teachers could invite adherents of religions under exploration to the schools in order to impart relevant information to the learners. In this way, learners would get first-hand information from the 'insider'.

\section{Possible Impediments of the Involvement of Religious Communities}

Finally, this study was also interested in establishing possible impediments of involving religious communities to the teaching and learning of a multi-faith syllabus on educational grounds. In this connection, the results reveal that majority of the religious communities are of the view that perhaps their involvement could lead to indoctrination on the one hand and devaluing other religions, on the other hand. The following verbatim quotes illustrate this argument:

Some members of other religions may go to schools to promote their religion and talk bad of others which will make the students judgmental of other religions.

Some religions will teach our children their religious values which may be contrary to our own value.

It can be gathered from these comments that whilst the involvement is capable of promoting knowledge acquisition by allowing learners to get first-hand information from the adherents of the religions under study, it can at the same time impede the teaching of this subject on educational grounds by promoting indoctrination and confessionalism.

Seemingly, majority of teachers were also of the view that this involvement has possible impediments to the teaching and learning of a multi faith syllabus because it is capable of indoctrinating students. For instance, it was argued that if religious communities are involved in the teaching of their religions at schools, they could take advantage of such an opportunity to spread their religions and convert students. The following extracts illustrate this argument:

The religious communities would come here to clear their religions names and not present the content the way we want it to be presented. 
They are preachers and not teachers, therefore they can derail our content; students might quote their preaching during the exam which will make them fail.

Interestingly, as can be realised, whilst religious communities and teachers appreciate the need to involve religious communities, they are at the same time aware of possible impediments of this involvement to the teaching and learning process of this subject. However, despite this awareness, some teachers argued that qualified RE teachers can address the problem of indoctrination by guiding learners to understand RE as a second order form of knowledge (Sealey, 1982), mainly aiming at imparting religious knowledge and understanding.

\section{CONCLUSION}

The findings of this study indicate that the involvement of religious communities in the teaching of a multi-faith syllabus could benefit both the teachers and the learners by providing first-hand information. As it emerged, such an involvement is capable of improving RE Junior Certificate Results. It is also evident from these findings that there could be obstacles in the process of involving the religious communities. However, this study further reveals that the advantages and benefits of involving religious communities outweigh the disadvantages. Based on such findings, this study therefore recommends the involvement of the religious communities in the teaching of the multi-faith RE syllabus in Botswana junior secondary schools.

\section{References}

Amanze, J. N. (2002). African Traditional Religions and Culture in Botswana. Gaborone: Pula Press.

Becker, R. (2001). Spiritual Care on the Rocks. The European Journal of Palliative Care, Vol.8(4).

Bhatti, R. Z. (2007). Synchronization and Timing Techniques Based on Statistical Random Sampling. USA: Proquest Information and Learning Company.

Blaikie, N. (2010). Designing Social Research. United Kingdom: Polity Press.

(1977). Botswana Government 1977. Education for Kagisano: A Report on the National Commission on Education. Gaborone: Gaborone Printer.

Botswana Government. Revised National Policy on Education. (1994). Gaborone: Government Printers.

(Botswana Examinations Council (BEC, 2013). 2012 Junior Certificate Examinations (JCE) results released by Botswana Examinations Council (BEC) http://www.bec.co.bw/news/2012-jce-results-released.

Cargan, L. (2007). Doing Social Research. USA: Rowman \& Littlefield Publishers, Inc.

Cheng, Y. C. (2005). New Paradigm for Reengineering Education: Globalization, Localization and Individualization. Netherlands: Springer.

Chidester, D. (1996). Savage Systems: Colonialism and Comparative Religion in Southern Africa. USA: University Press of Virginia.

Cottrell, R., \& McKenzie, J. (2011). Health Promotion and Education Research Methods: Using the Five-Chapter thesis/disserttation model. Sudbury, Mass: Jones \& Bartlett Publishers.

Deforges, C., \& Abouchaar, A. (2003). The Impact of Parental Involvement, Parental Support and Family Education on Pupil Achievement Adjustment: A Literature Review.

Dinku, G.T., (2002). The Role of Christian Living Today in the Promotion of Personal Development amonmg Senior Secondary Schools Students in Botswana, Unpublished M Ed Dissertation, University of Botswana.

Epstein, J. (2001). School, Family and Community Partnerships: Preparing Educators and Improving Schools. New York: Westview Press.

Grimmit, M. (1987). Religious Education and Human Development. England: Mc Crimmon Publishing CO LTD.

Hull, J. (1982). New Direction in Religious Education. London: The Falmer Press. 
Masheko, C., Chic, A.,Dema, T., Mosweu, T. Thekiso, T. \& Mmolai, S. (2016). The Involvement of Religious Communities in the Teachinng of Multifiath Syllabus in Botswana Junior Secondary Schools.. Advances in Social Sciences Research Journal, 3(13) $119-128$.

Jackson, R. (2004). Rethinking Religious Education and Plurality: Issues in Diversity and Pedagogy. New York: Routledge Falmer.

Jackson, R. (1997). Religious Education: An Interpretive Approach. London: Hodder \& Stoughton.

Kgokgwe, K.M. (1996). An Analysis of Methods and Activities in the teaching of Religious Education in Gaborone City and Southern District Primary Schools of Botswana in the Post Colonial Era, Unpublished MEd Dissertation, University of of Botswana.

Krysik, J., \& Finn, J. (2013). Research for Effective Social Work Practice. New York: Routledge.

Kumar, R. (2010). Research Methodology: A Step-by-Step Guide for Beginners. India: SAGE Publishers.

Matemba, Y. H. (2005). Multi- Faith Religious Education in Botswana. Religious Education: The Journal of the Religious Education Association, 100(2), 404- 424.

Miroshnikova, E., \& Davis, D. (2013). The Routledge International Handbook of Religious Education. U SA: Routledge.

Mmolai, S. (1998). Religious Education in Botswana Secondary Schools: Beginnings, Developments and Future Prospects. M. Ed, Thesis, Lancaster University.

Morake, L. (1993). A Conceptual Analysis of Botswana Senior School Religious Education Syllabus. M. Ed, Thesis, University of Botswana.

Muijs, D. (2011). Doing Quantitative Research in Education with SPSS (2nd edition). London: SAGE Publications. Nesbitt, E. (2004). Intercultural Education: Ethnographic and Religious Approaches. Brighton: Sussex Academic Press.

Nkomazana, F., \& Lanner, L. (2007). History of the Church in Botswana. South Africa: Cluster Publications.

Ornstein, A., Levine, D., Gutek, G., \& Vocke, D. (2013). Foundations of Education. USA: Wadsworth.

Schools Council, (1971). Religious Education in Secondary Schools (Working Paper 36), London: Methuen.

Seretse, T. E. (1990). Aims for Religious Education in Botswana in the 1990s. MA Dissertation. United Kingdom; University of Lancaster.

Singh, K., Bickley, P., Keith, P., Trivette, P., \& Anderson, E. (1995). The Effects of Four Components of Parental Involvement on Eight Grade Student Achievement: Structural Analysis of NELS-88 Data. School Psychology Review, 24(2), 299-317.

Smart, N. (1968). Secular Education and the Logic of Religion. New York: Faber.

Thompson, P. (2004). Whatever Happened to Religious Education. Britain: The Lutterworth Press.

Tlokwe, I. (2001). Religious Education and the Promotion of Social Harmony amongst Botswana Senior Secondary Students, Unpublished MEd Dissertation, University of Botswana.

Uemura, M. (1999). Community Participation in Education: What Do We Know? The World Bank. 